\title{
Improved Scalable Syntheses of Mono- and Bis-Urethane Derivatives of Ornithine ${ }^{1)}$
}

\author{
Stanisław WiejaK, ${ }^{a}$ Elżbieta Masiukiewicz, ${ }^{b}$ and Barbara RzEszotarsKA ${ }^{*, b}$ \\ Laboratory of Chemistry, Technical University of Opole, ${ }^{a} 7$ Luboszycka St, 45-036 Opole, Poland and Department of \\ Organic Chemistry, University of Opole, ${ }^{b} 48$ Oleska St, 45-052 Opole, Poland. \\ Received March 5, 2001; accepted April 22, 2001
}

In the search for a practical route to ornithine bisurethane derivatives useful for peptide synthesis, we elaborated the simple and efficient $\left(86 \%\right.$ yield) synthesis of $N^{\varepsilon}$-tert-butoxycarbonyl-L-ornithine copper(II) complex(1). This served as substrate for obtaining $N^{\varepsilon}$-tert-butoxycarbonyl-L-ornithine (2), $N^{\alpha}$-benzyloxycarbonyl- $N^{\varepsilon}$-tert-butoxycarbonyl-L-ornithine (3) and $N^{\alpha}$-(9-fluorenyl)methoxycarbonyl- $N^{\varepsilon}$-tert-butoxycarbonyl-L-ornithine (4). These were synthesized in $94-95 \%$ yields and with a purity above $99 \%$.

Key words $N^{\delta}$-Boc-L-ornithine; $N^{\alpha}$-Z- $N^{\delta}$-Boc-L-ornithine; $N^{\alpha}$ Fmoc- $N^{\delta}$-Boc-L-ornithine; $N^{\delta}$-Boc-L-ornithine copper(II) complex; peptide synthesis; 8-quinolinol

Ornithine $^{2)}$ is a non-coded amino acid which is frequently applied as a modifier in bioactive peptides, including drugs obtained industrially, to improve their biological properties $\left(\right.$ e.g. $\left.{ }^{3-8)}\right)$, and as the precursor of a coded amino acid, arginine to circumvent problems posed with its guanidino function through peptide syntheses. ${ }^{9)}$ Ornithine is also commonly used in place of the natural folate glutamic acid residue in research programs aimed at new effective antifolate drugs (e.g. ref. 10-14). Recent advances in the area of drug delivery have caused a resurgence of interest in the large scale production of peptides as pharmaceuticals. ${ }^{8)}$ Therefore, economically viable methods are desirable for the manufacturing of amino acid derivatives, among others of ornithine derivatives, useful to this end. The simplest route to orthogonally masked derivatives of ornithine is the simultaneous blockage of the $\alpha$-amino and $\alpha$-carboxyl function by copper complex, then $\delta$-amino group acylation, copper detachment and the introduction of further protection.

We report the simple, scalable syntheses of four ornithine compounds $1-4$ (Chart 1, Fig. 1), of which $N^{\delta}$-tert-butoxycarbonyl-L-ornithine copper(II) complex (1) serves for obtaining $N^{\delta}$-tert-butoxycarbonyl-L-ornithine (2) and for direct one-pot, almost quantitative preparation of $N^{\alpha}$-benzyloxycarbonyl- $N^{\delta}$-tert-butoxycarbonyl-L-ornithine (3) and $N^{\alpha}$-(9-fluorenyl)methoxycarbonyl- $N^{\delta}$-tert-butoxycarbonyl-L-ornithine (4). The described methods are based on those recently elaborated in our laboratories for the parallel derivatives of the congeneric amino acid, lysine, ${ }^{15)}$ but, owing to quite significant differences in the solubility properties between the corresponding lysine and ornithine compounds, some critical modifications were either possible or needed, which are delineated herein.

The majority of procedures for preparing $\mathrm{Orn}_{2} \mathrm{Cu}^{3,4,16,17)}$ apply a basic copper carbonate of approximate formula $\mathrm{CuCO}_{3} \cdot \mathrm{Cu}(\mathrm{OH})_{2} \cdot \mathrm{H}_{2} \mathrm{O}$ as a copper source and $\mathrm{NaHCO}_{3}$ as an alkaline factor. This route to the complex requires heating and filtration and leads after $N^{\delta}$-tert-butoxycarbonylation to $[\mathrm{Orn}(\mathrm{Boc})]_{2} \mathrm{Cu}(\mathbf{1})$ in $66 \%$ yield to the maximum. ${ }^{17)}$ Another copper reagent is $\mathrm{CuSO}_{4} \cdot 5 \mathrm{H}_{2} \mathrm{O}{ }^{13,15,18)}$ For the preparation of $\mathbf{1}$, isolated in $79 \%$ yield, ${ }^{18)}$ as well as of $[\mathrm{Lys}(\mathrm{Boc})]_{2} \mathrm{Cu}$, isolated in $94 \%$ yield ${ }^{15}$ ) we previously just employed $\mathrm{CuSO}_{4}$ and either $\mathrm{NaOH}^{18)}$ or $\mathrm{NaHCO}_{3},{ }^{15)}$ respectively, for the com- plex formation followed by $\mathrm{Boc}_{2} \mathrm{O}$ and $\mathrm{NaHCO}_{3}$ for the $N^{\delta}$-tert-butoxycarbonylation. An attempt to produce [Orn(Boc) $]_{2} \mathrm{Cu}$ according to ref. 15 also gave $80 \%$ yield only. The cause of this is that the water solubility of this compound is better than that of the lysine one. Therefore, in the present work on the synthesis of the ornithine copper complex $(\mathrm{Orn})_{2} \mathrm{Cu}$, we used $\mathrm{Cu}\left(\mathrm{CH}_{3} \mathrm{COO}\right)_{2}$ and $\mathrm{NaOH},{ }^{11)}$ which first allowed us to conduct the reaction in less water. Secondly, the resulting $\mathrm{CH}_{3} \mathrm{COONa}$ confers the appropriate $\mathrm{pH}$ on the reaction medium. This permitted us to avoid the extra alkali always applied ${ }^{3,4,15-18)}$ for the catalysis of the subsequent $N^{\delta}$ tert-butoxycarbonylation process. Thirdly and most importantly, the tert-butoxycarbonylation could be carried out in an organic-aqueous medium, acetone-water $(4: 3)$ instead of an aqueous-organic one, water-acetone $(2: 1)$ characteristic of the manufacturing of $[\mathrm{Lys}(\mathrm{Boc})]_{2} \mathrm{Cu} .{ }^{15)}$ This offered a significant facilitation in operability, in the form of a filtrationfriendly $[\mathrm{Orn}(\mathrm{Boc})]_{2} \mathrm{Cu}$ precipitate. This way, the decomposition of unreacted $\mathrm{Boc}_{2} \mathrm{O}$ with methanol, needed for the high purity of $[\mathrm{Lys}(\mathrm{Boc})]_{2} \mathrm{Cu},{ }^{15)}$ could be eliminated here, because only stirring the $[\mathrm{Orn}(\mathrm{Boc})]_{2} \mathrm{Cu}$ complex with acetone and washing the resulting filtered-off precipitate with a small amount of this solvent was sufficient. As the net result of all these modifications, the protocol for the $[\mathrm{Orn}(\mathrm{Boc})]_{2} \mathrm{Cu}$ synthesis was simplified as much as possible and furnished $\mathbf{1}$ in $86 \%$ yield (lit. ${ }^{4,17,18)} 53 \%, 66 \%$ and $79 \%$ yield, respectively). The product was homogenous by TLC and had correct elemental analysis.

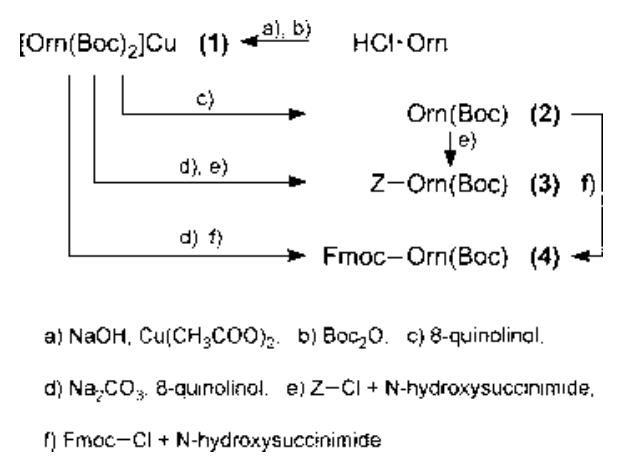

Chart 1. Synthesis of Mono- and Bis-Urethane Derivatives of Ornithine 


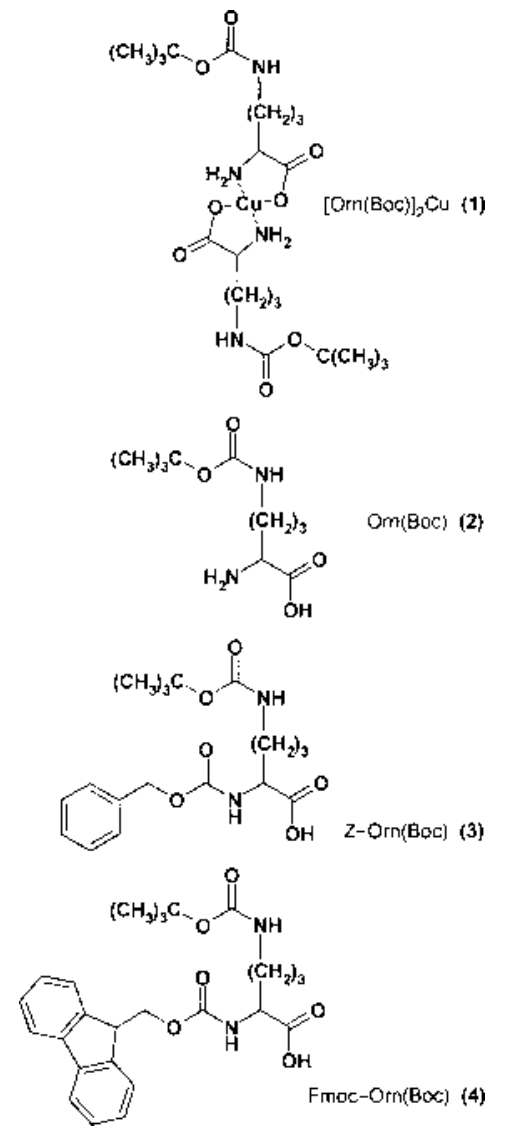

Fig. 1. Structures of the Compounds Synthesized in this Work

We removed copper from $\mathbf{1}$ in an aqueous suspension with 8-quinolinol, originally proposed and previously well verified by us as a new complexone in peptide chemistry. ${ }^{15)}$ Advantageously, the present product, $\operatorname{Orn}(\mathrm{Boc}) \mathbf{2}$ is much more water-soluble than $\mathrm{Lys}(\mathrm{Boc})$ and does not precipitate at copper quinolinate as the lysine derivative did. ${ }^{15)}$ Therefore, we were able (i) to use less water as the suspension medium than needed in Lys(Boc) production, and (ii) to avoid the severalhour maceration of copper quinolinate in water required for a high Lys(Boc) yield. The first (i) is feasible provided that prior to due copper exchange, complex $\mathbf{1}$ is pre-wetted with small amounts of acetone and then of water. The second (ii) is dispensable, because ordinary washing of the quinolinate with water was sufficient to secure Orn(Boc) in $94 \%$ yield ( $81 \%$ based on Orn), homogenous by TLC and of correct elemental analysis. With a classical copper sequestrator, the yields amount to only $65 \%$ (34\% based on $\left.\mathrm{Orn}^{4}\right)$ and $69 \%$ $\left(46 \%\right.$ based on $\left.\operatorname{Orn}^{17}\right)$. The product is useful for preparing Z-Orn(Boc) (3) and Fmoc-Orn(Boc) (4) applied, respectively, in the $\alpha-\mathrm{Z}-\omega-t-\mathrm{Bu}^{19)}$ and $\alpha$-Fmoc- $\omega$-t-Bu ${ }^{20)}$ peptide synthesis strategy, for preparing other bisurethane derivatives including those of a new generation, e.g. Bsmoc-Orn(Boc), ${ }^{21)}$ as well as for preparing antifolate $N^{\delta}$-masked ornithine analogs. ${ }^{13,14)}$

The bisurethane ornithine derivatives, Z-Orn(Boc) 3 and Fmoc-Orn(Boc) 4 can be directly obtained from copper complex $[\mathrm{Orn}(\mathrm{Boc})]_{2} \mathrm{Cu} \mathbf{1}$ in the presence of 8-quinolinol, omitting the above separate copper removal step. To gain products of high quality, as was the case for the related Lys derivative, ${ }^{15)}$ benzyl or 9 -fluorenylmethyl $N$-succinimidyl carbon- ate is needed to introduce the $\delta$-urethane group. As previously, these reagents can be applied in situ prepared in a separate vessel. Details of the work-up procedures for the production of $\mathbf{3}$ and $\mathbf{4}$, however, had to be modified. The sodium salts of $\mathbf{3}$ and $\mathbf{4}$ being well water-soluble, at the same time, strongly opposed to the congeneric Lys compounds, are also well (3) or even very well (4) soluble in ethyl acetate, commonly used for extractive procedures in amino acid derivative and peptide chemistry. The sodium salts of $\mathbf{3}$ and $\mathbf{4}$ proved, however, to be insoluble in dichloromethane and toluene, respectively, which allowed for extracting from their aqueous solutions minute quantities of organic post-reaction impurities, collected through all steps of these one-pot procedures. Eventually, this leaves very pure final products, $\mathbf{3}$ and 4, above $99 \%$ as determined by HPLC, and in high yields, $94 \%$ and $95 \%$, respectively.

All described methods display a high degree of convenience and practicality and lend themselves to be scaled up.

\section{Experimental}

General Experimental Procedures $\mathrm{HCl} \cdot$ Orn came from Fluka (\#75 470). Reactions were monitored and the homogeneity of products was checked on silica gel plates (DC Alufolien Kieselgel 0.25 Merck \#5553) using the following solvent systems (v/v): A, $n$ - BuOH : $\mathrm{AcOH}: \mathrm{AcOEt}: \mathrm{H}_{2} \mathrm{O}$ $(1: 1: 1: 1)$; $\mathrm{B}, \mathrm{CHCl}_{3}: \mathrm{MeOH}: \mathrm{AcOH}(95: 5: 3)$. Spots were visualised with ninhydrin and chlorine-KI-tolidine reagent. Organic solutions were dried over anhydrous $\mathrm{Na}_{2} \mathrm{SO}_{4}$. The solvents from reaction mixtures were removed in vacuo on a rotatory evaporator at bath temperatures not exceeding $45^{\circ} \mathrm{C}$. Melting points were determined by means of differential scanning calorimetry (DSC) in a calorimeter DSC-2010 (Thermal Analysis Instruments) under nitrogen in a closed copper vessel with a heating rate of $10^{\circ} \mathrm{C} / \mathrm{min}$. HPLC analyses were carried out using a Beckman System Gold chromatograph, a $5 \mu \mathrm{l}$ loop, an Alltech Alltima, $\mathrm{C}_{18}, 5 \mu \mathrm{m}, 150 \times 4.6 \mathrm{~mm}$ column, $0.1 \%$ trifluoroacetic acid : acetonitrile $(50: 50 ; \mathrm{v} / \mathrm{v})$ as a mobile phase with a flow rate of $1 \mathrm{ml} / \mathrm{min}$ and detection at $210 \mathrm{~nm}$. Specific rotations were measured on a Jasco DIP-1000 polarimeter.

Copper(II) Complex of $\boldsymbol{N}^{\delta}$-tert-Butoxycarbonyl-L-ornithine ([Orn(Boc) $]_{2}$ Cu) (1) To a stirred solution of $\mathrm{HCl} \cdot \mathrm{Orn}(16.862 \mathrm{~g}, 100 \mathrm{mmol})$ in $2 \mathrm{M} \mathrm{NaOH}(100 \mathrm{ml})$, a solution $\mathrm{Cu}\left(\mathrm{CH}_{3} \mathrm{COO}\right)_{2} \cdot \mathrm{H}_{2} \mathrm{O}(9.982 \mathrm{~g}, 50 \mathrm{mmol})$ in water $(50 \mathrm{ml})$ was introduced followed by a solution of $96 \% \mathrm{Boc}_{2} \mathrm{O}(28.73 \mathrm{~g}$, $130 \mathrm{mmol})$ in acetone of technical quality $(200 \mathrm{ml})$. After $24 \mathrm{~h}$, the additional portion of acetone $(100 \mathrm{ml})$ was introduced and stirring continued for $20 \mathrm{~h}$. The precipitate was filtered off and washed with a mixture of acetone: water $(2: 1)(200 \mathrm{ml})$ and water $(2 \times 500 \mathrm{ml})$. The resulting fine, light blue solid was air-dried to yield $1(22.57 \mathrm{~g}, 86 \%)$, mp $245.89^{\circ} \mathrm{C}$ (lit. ${ }^{17)} \mathrm{mp}$ $244^{\circ} \mathrm{C}$ ); $R f(\mathrm{~A})$ 0.68. Anal. Calcd for $\mathrm{C}_{20} \mathrm{H}_{38} \mathrm{CuN}_{4} \mathrm{O}_{8}: \mathrm{C}, 45.66 ; \mathrm{H}, 7.28 ; \mathrm{N}$, 10.65. Found: C, $45.47 ; \mathrm{H}, 7.49$; N, 10.43 .

$N^{\delta}$-tert-Butoxycarbonyl-L-ornithine (Orn(Boc)) (2) A suspension of $\left[\mathrm{Orn}(\mathrm{Boc})_{2}\right] \mathrm{Cu}(13.152 \mathrm{~g}, 25 \mathrm{mmol})$ in acetone $(50 \mathrm{ml})$ was intensively stirred for $15 \mathrm{~min}$, water $(50 \mathrm{ml})$ added and stirring continued for $10 \mathrm{~min}$. Then, water $(300 \mathrm{ml})$ and 8 -quinolinol $(9.45 \mathrm{~g}, 65 \mathrm{mmol})$ were introduced and stirring was continued for a further $4 \mathrm{~h}$. The precipitate of copper(II) quinolinolate was filtered off and washed with water $(2 \times 25 \mathrm{ml})$. The filtrate and washings were combined and acetone was evaporated. The residual aqueous solution was extracted with ethyl acetate $(3 \times 100 \mathrm{ml})$ (discarded) and evaporated to give $2(10.90 \mathrm{~g}, 94 \%), \mathrm{mp} 209.75^{\circ} \mathrm{C}$ and then dec. $235.30^{\circ} \mathrm{C}$ (lit. ${ }^{3)} \mathrm{mp} 180{ }^{\circ} \mathrm{C}$, lit. $\left.{ }^{10)} \mathrm{mp} 220-222^{\circ} \mathrm{C}\right) ;[\alpha]_{\mathrm{D}}^{20}=15.2^{\circ}(c 1.0$, AcOH) (lit. $\left.{ }^{4}[\alpha]_{\mathrm{D}}^{20}=13.4 \pm 0.2^{\circ}(c 1.0, \mathrm{AcOH})\right) ; R f(\mathrm{~A}) 0.68$. Anal. Calcd for $\mathrm{C}_{10} \mathrm{H}_{20} \mathrm{~N}_{2} \mathrm{O}_{4}: \mathrm{C}, 51.71 ; \mathrm{H}, 8.68 ; \mathrm{N}, 12.06$. Found: $\mathrm{C}, 51.64 ; \mathrm{H}, 8.81 ; \mathrm{N}$, 12.13 .

$N^{\alpha}$-Benzyloxycarbonyl- $N^{\delta}$-tert-butoxycarbonyl-L-ornithine (Z-Orn(Boc)) (3) A suspension of [Orn $(\mathrm{Boc})]_{2} \mathrm{Cu}(10.52 \mathrm{~g}, 20 \mathrm{mmol})$ in acetone $(40 \mathrm{ml})$ was intensively stirred for $15 \mathrm{~min}$, water $(40 \mathrm{ml})$ added and stirring continued for $10 \mathrm{~min}$. Then, $10 \%$ aqueous $\mathrm{Na}_{2} \mathrm{CO}_{3}$ solution $(80 \mathrm{ml})$ and $8-$ quinolinol $(5.99 \mathrm{~g}, 41.2 \mathrm{mmol})$ were introduced. The mixture resulting after $1 \mathrm{~h}$ is called reaction mixture 1 and was subsequently used. To a solution of $N$-hydroxysuccinimide $(5.06 \mathrm{~g}, 44 \mathrm{mmol})$ in water $(24 \mathrm{ml})$ placed in a separate vessel, $\mathrm{Na}_{2} \mathrm{CO}_{3}(2.32 \mathrm{~g}, 22 \mathrm{mmol})$ was added, followed by acetone $(40 \mathrm{ml})$ and the mixture was cooled to $-5^{\circ} \mathrm{C}$. Benzyl chlorocarbonate of $96 \%$ purity $(6.2 \mathrm{ml}, 40 \mathrm{mmol})$ was introduced in portions to maintain this 
temperature. The whole was left standing at $-5^{\circ} \mathrm{C}$ for a half hour with occasional stirring to give reaction mixture 2 . This was poured into stirred reaction mixture 1 . After $1 \mathrm{~h}$, the precipitate of copper quinolinate was filtered off and washed with water. The filtrate and washings were combined and acetone was evaporated. The residual aqueous solution was extracted with dichloromethane $(3 \times 50 \mathrm{ml})$ (discarded), acidified under stirring with $1 \mathrm{M}$ $\mathrm{HCl}$ to $\mathrm{pH} 2$ and extracted with ethyl acetate $(3 \times 70 \mathrm{ml})$. The acetate phase was washed with $0.25 \mathrm{M} \mathrm{HCl}(50 \mathrm{ml})$ and brine, dried, evaporated and crystallized from ethyl acetate/hexane to furnish $3(13.86 \mathrm{~g}, 95 \%), R f(\mathrm{~B}) 0.60 ; t_{\mathrm{R}}$ $5.12 \mathrm{~min}, 99.1 \%$ purity.

For analytical purposes, the product $(1.00 \mathrm{~g})$ was crystallized from ethyl acetate $(3 \mathrm{ml}) /$ hexane $(5 \mathrm{ml})$ to give $3(0.92 \mathrm{~g}), \mathrm{mp} 106.27^{\circ} \mathrm{C}$ (lit. ${ }^{3)} \mathrm{mp}$ $101{ }^{\circ} \mathrm{C}$, lit. ${ }^{18)} \mathrm{mp} 99.5-101^{\circ} \mathrm{C}$, lit. $\left.^{22)} \mathrm{mp} 97-99^{\circ} \mathrm{C}\right) ;[\alpha]_{\mathrm{D}}^{20}=-2.27 \pm$ $0.06^{\circ}$ (c 1.0, methanol) (lit. ${ }^{3)}[\alpha]_{\mathrm{D}}^{20}=-3.2 \pm 0.6^{\circ}$ (c 2.45, methanol)); $100 \%$ purity by HPLC. Anal. Calcd for $\mathrm{C}_{18} \mathrm{H}_{26} \mathrm{~N}_{2} \mathrm{O}_{4}$ : C, 59.00; H, 7.15; N, 7.65. Found: C, 58.95; H, 7.21; N, 7.53.

$N^{\alpha}$-(9-Fluorenyl)methoxycarbonyl- $N^{\delta}$-tert-butoxycarbonyl-L-ornithine (Fmoc-Orn(Boc)) (4) Reaction mixture 1 was obtained in exactly the same way as for 3. To a solution of $N$-hydroxysuccinimide $(4.86 \mathrm{~g}, 42.24$ $\mathrm{mmol})$ in water $(24 \mathrm{ml})$ placed in a separate vessel, $\mathrm{Na}_{2} \mathrm{CO}_{3}(2.24 \mathrm{~g}, 21.2$ $\mathrm{mmol}$ ) was introduced, followed by 9-fluorenylmethyl chlorocarbonate $(9.92 \mathrm{~g}, 38.4 \mathrm{mmol})$ in acetone $(40 \mathrm{ml})$. The whole was left standing for a half hour with occasional stirring to give reaction mixture 2 . This was poured into stirred reaction mixture 1 . After $1 \mathrm{~h}$, the precipitate of copper quinolinate was filtered off and washed with water $(100 \mathrm{ml})$. The filtrate and washings were combined and acetone was evaporated. The residual aqueous solution was extracted with toluene $(2 \times 40 \mathrm{ml}$ and $1 \times 15 \mathrm{ml})($ discarded $)$ and then with ethyl acetate $(3 \times 70 \mathrm{ml})$. The acetate layer was extracted with $0.5 \mathrm{M}$ $\mathrm{HCl}(100 \mathrm{ml}), 0.25 \mathrm{M} \mathrm{HCl}(2 \times 60 \mathrm{ml})$ and brine, dried and thoroughly evaporated. Ethyl acetate $(80 \mathrm{ml})$ was added to give a product like lyogel. The solvent was evaporated to leave needles. These were re-dissolved in ethyl acetate $(80 \mathrm{ml})$ under reflux. The solution was cooled to $20^{\circ} \mathrm{C}$ and hexane $(60 \mathrm{ml})$ added. The whole was left standing in a refrigerator overnight. The resulting crystals were filtered off, washed with a mixture of ethyl acetate : hexane $(1: 3)$ to furnish $4(16.72 \mathrm{~g}, 94 \%), \mathrm{mp} 112.51^{\circ} \mathrm{C}$ (lit. ${ }^{23)} \mathrm{mp}$ $\left.113-116^{\circ} \mathrm{C}\right) ;[\alpha]_{\mathrm{D}}^{20}=-7.95 \pm 0.07^{\circ}(c 1.0, \mathrm{DMF})\left(\right.$ lit. $^{23)}[\alpha]_{\mathrm{D}}^{20}=-6.8^{\circ}(c$ 1.0, DMF)); Rf (B) $0.57 ; t_{\mathrm{R}} 14.37 \mathrm{~min}, 100 \%$ purity. Anal. Calcd for $\mathrm{C}_{25} \mathrm{H}_{30} \mathrm{~N}_{2} \mathrm{O}_{6} \cdot 0.5 \mathrm{H}_{2} \mathrm{O}: \mathrm{C}, 64.78 ; \mathrm{H}, 6.74 ; \mathrm{N}, 6.04$. Found: C, 64.49; H, 6.96; $\mathrm{N}, 5.94$.

Acknowledgement The authors acknowledge financial support for this work by a grant-in-aid from the Polish State Committee for Scientific Research $(\mathrm{KBN})$

\section{References and Notes}

1) The methods for preparing the described compounds are the object of Polish Patent Application P 344 809, P 344810 (2000) and P 345912 (2001).

2) Abbreviations: Orn $=\mathrm{L}$-ornithine, Lys $=\mathrm{L}-\mathrm{lysine}$, Boc $=$ tert-butoxycarbonyl, $\mathrm{Z}=$ benzyloxycarbonyl, Fmoc=9-fluorenylmethoxycarbonyl, Bsmoc $=1,1$-dioxobenzo $[b]$ thiophene-2-ylmethyloxycarbonyl.

3) Tesser G. I., Schwyzer R., Helv. Chim. Acta, 49, 1013-1022 (1966).

4) Marchiori F., Rocchi R., Vidali G., Tamburro A., Scoffone E., J. Chem. Soc. C, 1967, 81-85.

5) Janáky T., Juhász A., Bajusz S., Csernus V., Srkalovic G., Bokser L.,
Milovanovic S., Redding T. W., Rékási Z., Nagy A., Schally A. V., Proc. Natl. Acad. Sci. U.S.A., 89, 972-976 (1992); Janáky T., Juhász A., Rékási Z., Serfözö P., Piński J., Bokser L., Srkalovic G., Milovanovic S., Redding T. W., Halmos G., Nagy A., Schally A. V., ibid., 89, 10203 -10207 (1992); Izdebski J., Piński J., Horvath J. E., Halmos G., Groot K., Schally A. V., ibid., 92, 4872—4876 (1995); Zarándi M., Schally A. V., Kovács M., Horváth J. E., Tóth K., Varga J., Nagy A., Kele Z., "Peptides 1998. Proc. 25th Eur. Pept. Symp.," ed. by Bajusz S., Hudecz F., Akadémiai Kiadó, Budapest, 1999, pp. 648-649; Witkowska E., Orłowska A., Sagan B., Smoluch M., Izdebski J., J. Peptide Sci., 7, 166-172 (2001).

6) Pawlak D., Oleszczuk M., Wójcik J., Pachulska M., Chung N. N., Schiller P. W., Izdebski J., J. Peptide Sci., 7, 128-140 (2001).

7) Johansson C., Blomberg L., Hlebowicz E., Nicklasson H., Nilsson B., Andersson L., "Peptides 1994. Proc. 23rd Eur. Pept. Symp.," ed. by Maia H. L. S., ESCOM, Leiden, 1995, pp. 34-35.

8) Andersson L., Blomberg L., Flegel M., Lepsa L., Nilsson B., Verlander M., Biopolymers (Peptide Science), 55, 227-250 (2000).

9) Bodanszky M., "Peptide Chemistry: A Practical Textbook," Springer Verlag, Berlin, 1993, p. 99

10) Rosowsky A., Freisheim J. H., Moran R. G., Solan V. C., Bader H., Wright J. E., Radike-Smith M., J. Med. Chem., 29, 655-660 (1986).

11) Rosowsky A., Vaidya Ch. M., Bader H., Wright J. E., Teicher B. A., J. Med. Chem., 40, 286-299 (1997).

12) Matsuoka H., Kato N., Ohi N., Miyamoto K., Mihara M., Takeda Y., Chem. Pharm. Bull., 45, 1146-1150 (1997).

13) Itoh F., Yoshioka Y., Yukishige K., Yoshida S., Ootsu K., Akimoto H., Chem. Pharm. Bull., 48, 1270-1280 (2000).

14) Rosowsky A., Wright J. E., Vaidya Ch. M., Forsch R. A., Bader H., J. Med. Chem., 43, 1620-1634 (2000).

15) Wiejak S., Masiukiewicz E., Rzeszotarska B., Chem. Pharm. Bull., 47, 1489-1490 (1999).

16) Boeckman R. K., Jr., Perni R. B., J. Org. Chem., 51, 5486-5489 (1986).

17) Paquette L. A., Macdonald D., Anderson L. G., J. Am. Chem. Soc., 112, 9292-9299 (1990).

18) Masiukiewicz E., Rzeszotarska B., Szczerbaniewicz J., Org. Prep. Proced. Int., 24, 191-194 (1992).

19) Schwyzer R., "Protides in the Biological Fluids," Vol. 9, ed. by Peters H., Elsevier Publishing Company, Amsterdam, 1962, p. 27; Mehta A., Jaouhari R., Benson T. J., Douglas K. T., Tetrahedron Lett., 33, 54415444 (1992).

20) Atherton E., Fox H., Harkiss D., Logan C. J., Sheppard R. C., Williams B. J., J. Chem. Soc. Chem. Comm., 1978, 537-539; Meienhofer J., Waki M., Heimer E. P., Lamros T. J., Makofske R. C., Int. J. Peptide Protein Res., 13, 35-42 (1979); Atherton E., Sheppard R. C., "The Peptides. Analysis, Synthesis, Biology," Vol. 9, ed. by Udenfriend S., Meienhofer J., Academic Press, San Diego, 1987, pp. 1-38.

21) Carpino L. A., Ismail M., Truran G. A., Mansour E. M. E., Iguchi S., Ionescu D., El-Faham A., Riemer C., Warrass R., J. Org. Chem., 64, 4324-4338 (1999).

22) Schnabel E., Liebigs Ann. Chem., 702, 188-196 (1964).

23) Fields G. B., Noble R. L., Int. J. Peptide Protein Res., 35, 161-214 (1990). 